\section{A ocorrência da dengue e \\ variações meteorológicas no \\ Brasil: revisão sistemática}

\section{The ocurrence of dengue and weather changes in Brazil: $A$ systematic review}

\section{Abstract}

Introduction: Dengue is configures in recent decades as an important cause of morbidity and mortality in Brazil and around the world reaching the tropical and subtropical areas. Objective: To review the scientific literature on the occurrence of dengue in Brazil and its relationship with meteorological variables. Method: A systematic review of studies published in databases (SciELO, PubMed, MEDLINE, Lilacs) using descriptors related to weather variations and dengue fever in Brazil, published between 1991 to 2010. It was selected 31 articles that had the study area nationwide. Results: Most epidemiological studies use ecological design, the studies make use of entomological trapping, are common also series of studies of the disease and spatial analysis. It is evident relationship between dengue incidence with temperature and rainfall, the association is more significant from the second to fourth months of the year. Comparative studies of drought and rain show seasonal behavior of the disease. There are difficulties in establishing unique pattern of seasonality of disease incidence and weather variables for the country. Conclusion: Dengue is strongly related to meteorological variables. The seasonal variation in temperature and rainfall influences the dynamics of the vector and the incidence of the disease throughout the country, regardless of the climate category.

Keywords: Dengue. Aedes. Epidemiology. Environmental health. Climate. Incidence. Systematic Review.

\section{Dione Viero Viana ${ }^{\prime, 11}$ \\ Eliane Ignotti,,II \\ ' Public Health Institute of the Federal University of Mato Grosso (ISC/UFMT), Cuiabá, MT. \\ "School of Health of the State of Mato Grosso University, Cáceres, MT.}

The authors state that there are no conflicts of interest related to the publication of this paper. Corresponding author: Dione Viero Viana. Rua Brasília, 118 - Bairro Areão, 78010-265 Cuiabá, MT

- Brazil. E-mail: dionevieronev@gmail.com 


\section{Resumo}

Introdução: A dengue configura-se nas últimas décadas como importante causa de morbidade e mortalidade no Brasil e no mundo atingindo as zonas tropicais $\mathrm{e}$ subtropicais. Objetivo: Revisar a literatura científica sobre a ocorrência da dengue no Brasil e sua relação com variáveis meteorológicas. Método: Revisão sistemática de estudos publicados nas bases de dados (SciELO, PubMed, MEDLINE, Lilacs) através de descritores referentes à dengue $\mathrm{e}$ a variações meteorológicas no Brasil, em artigos publicados no período de 1991 a 2010. Foram selecionados 31 artigos que tiveram como área de estudo o território nacional. Resultados: A maioria dos estudos epidemiológicos usa desenho ecológico; os estudos entomológicos fazem uso de capturas com armadilhas; são comuns estudos de série histórica da doença e análise espacial. Evidencia-se relação entre incidência da dengue com a temperatura e pluviosidade; a associação é mais expressiva a partir do segundo até o quarto mês do ano. Estudos comparativos entre períodos de seca e chuva mostram comportamento sazonal da doença. Há dificuldades no estabelecimento de padrão único sazonal da incidência da doença e variáveis meteorológicas para o país. Conclusão: A dengue está fortemente relacionada com variáveis meteorológicas. A variação sazonal da temperatura e da pluviosidade influenciaram a dinâmica do vetor e a incidência da doença em todo o país, independente do compartimento climático.

Palavras-chave: Dengue. Aedes. Epidemiologia. Saúde ambiental. Clima. Incidência. Revisão sistemática.

\section{Introduction}

Nowadays, dengue is the most prevalent arthropod-borne virosis in the world, with approximately $40 \%$ of the population at risk $^{1}$. Four serotypes of the virus circulate, significantly increasing the severe and lethal forms of the disease ${ }^{2,3}$.

The number of cases of classic dengue and of dengue hemorrhagic fever has been increasing on an annual basis. It is estimated that 550 thousand hospitalizations with 20 thousand deaths occur per year among a total of approximately 2.5 billion exposed people $^{4,5}$, and an average of 80 million new cases are reported every year ${ }^{2}$.

As a reemerging endemic or pandemic disease, it occurs practically in all the tropical and subtropical regions of the planet ${ }^{1}$. The countries located in these regions are more susceptible due to diverse conditioning factors, such as: global changes, climate changes, weather variability, land use, water storage and irrigation, human population growth and urbanization ${ }^{6}$. Such factors, among others, significantly contribute to the proliferation and development of the Aedes aegyptimosquito - the virus vector ${ }^{7-9}$. Climate changes contribute to increase the number of people exposed to dengue to more than 2 billion and the projections for 2085 suggest that approximately 5 to 6 billion people (50 to $60 \%$ of the world's population) will be at risk regarding the disease transmission ${ }^{10}$.

The seasonal dynamics of the dengue vector is commonly associated with climate changes and fluctuations ${ }^{9,11}$, which include: temperature increase and variations in rainfall and relative air humidity, conditions that favor a higher number of available breeding sites and, consequently, the development of the vector. The latter presents two distinct stages: aquatic, with the development phases of egg, larva and pupa, and terrestrial, which corresponds to the adult mosquito. Both stages are subject to environmental and climate changes ${ }^{12,13}$.

In Brazil, the introduction of laboratory testing for dengue dates back to 1981-1982, in the city of Boa Vista, State of Roraima 
- in the Brazilian Amazon -, where the serotypes DENV-1 and 4 were isolated, with 11,000 confirmed cases $^{14}$. Since then, the country has undergone several epidemic outbreaks ${ }^{15,16}$.

Ae. Aegypti dispersal currently reaches the 27 Brazilian Federative Units, with more than 3,587 cities infested with the disease vector. In recent decades, dengue has become an important cause of morbidity and mortality ${ }^{17,18}$.

Brazil is considered a tropical country because it is located at low latitude zones, in which hot and humid climates prevail, with average temperatures around $20^{\circ} \mathrm{C}^{19}$. With an area of 8.5 million $\mathrm{km}^{2}$, the country is formed by five geographical regions (North, Northeast, Center-West, Southeast and South) and five climate zones: Equatorial, Temperate, Central Brazil Tropical, Eastern Northeast Tropical and Equatorial Zone Tropical ${ }^{20}$.

Brazil's climate variability is due to the territory's dimension, the size of the coastal strip, altitude variation and, mainly, to the presence of different air masses that modify the temperature and humidity conditions of the five regions. For this reason, the country's climate ranges from hot, superhumid climates deriving from equatorial air masses, as it is the case of a large part of the Amazon region, to semi-arid climates, typical of the Northeastern backlands ${ }^{20,21}$.

Considering the diverse studies that show the relation between environmental determinants and climate factors under the dynamics of endemics, and in view of the pertinence and magnitude of dengue in Brazil and in the world, the development of a literature review becomes relevant. This study aims to present a systematic review of the Brazilian scientific literature on the occurrence of dengue and its relationship to climate variables.

\section{Methodology}

\section{Study design}

This study is a systematic bibliographic review carried out in different scientific electronic databases, using descriptors referring to dengue and climate variables in Brazil. The identification of the papers and their inclusion occurred in the first semester of 2010.

\section{Electronic databases}

The bibliographical survey was conducted in the following electronic databases: Scientific Electronic Library Online - SciELO; (2) Medical Literature Analysis and Retrieved System - MEDLINE; (3) Literatura Latino-americana e do Caribe em Ciências da Saúde - Lilacs; (4) U.S. National Library of Medicine - PubMed.

Complementary information was obtained from epidemiological bulletins; reports on climate and environmental changes published by the World Health Organization (WHO), Pan-American Health Organization (PAHO) and Brazil's Ministry of Health; geographical and climate data provided by the Instituto Brasileiro de Geografia e Estatística (IBGE - Brazilian Institute of Geography and Statistics). A manual search was also performed, based on the references listed in the papers that were included in the review.

\section{Search strategies}

The searches were performed through descriptors registered in the Descritor em Ciências da Saúde (DeCS - Health Sciences Descriptor) and in the Medical Subject Headings - MeSH, in Portuguese and in English, which were present in the studies' titles or abstracts. To facilitate the search, the Boolean operators "AND" and "OR" were used, as well as quotation marks.

The combinations of terms used together or separately in the respective databases (SciELO, PubMed, Medline, LILACS) were:

- "Dengue (dengue)";

- "Aedes (Aedes)";

- "Dengue variáveis meteorológicas (dengue meteorological variables)";

- "Dengue fatores climáticos (dengue climatic factors)"; 
- "Dengue temperatura (dengue temperature)";

- "Dengue umidade (dengue humidity)";

- "Dengue verão (dengue summer)";

- Dengue chuva (dengue rain);

- "Dengue inverno (dengue winter)";

- Dengue pluviosidade (dengue rainfall)".

\section{Selection and analysis of publications}

To select the papers, a form was constructed with the following information: author and year, journal, title, period of development of the study, federative unit, city and area of the research, study design, inclusion in databases, descriptor used to locate the paper, statistical analysis method, objective and main results.

The inclusion criteria were: original papers published in international or national journals, in English, Portuguese or Spanish, independently of the year of publication, included in one of the databases mentioned above.

Only papers that contained analyses of meteorological variables and the relationship to the occurrence of dengue in Brazil were selected to the review. Studies that used Aedes aegypti as the main transmission vector, as well as Aedes albopictus, among others of lower prevalence, were included.

Overall, 625 scientific papers relating dengue to environmental/meteorological factors in Brazil and in the world were identified. Of the total of 43 papers that were produced with Brazilian data, 12 studies were excluded, either because they were not related to the review's theme or because they were duplicated. Thus, 31 papers were selected to be included in this scientific literature review. The results obtained through the application of the search strategy that was described above are shown in the study's logical framework.

The studies are presented in maps by Federative Units, geographical regions and according to the country's climate zones. In addition, they are presented in a table according to publication chronology, climate, place of study, meteorological variables and main findings. The results and discussion are presented below, divided into rainfall, rainfall/temperature, temperature/relative air humidity, and lag.

\section{Results and discussion}

\section{Reviewed papers}

Of the overall number of 31 (thirty-one) original and distinct papers included in the review, 12 (twelve) publications concentrate on temperature $\left({ }^{\circ} \mathrm{C}\right)$ and rainfall $(\mathrm{mm}) ; 9$ (nine) approach rainfall; 7 (seven) papers focus on temperature, rainfall, atmospheric pressure, wind direction and relative air humidity; 1 (one) study mentioned the abiotic factor quarterly and semi-annual temperature of each year; 1 (one) study compared distinct rain and drought periods; 1 (one) publication referred to summer/winter seasonal differentiation in relation to the incidence of dengue (Figure 1).

It was found that all the studies used quantitative approaches, and that the main methods employed in the studies were: capturing mosquitoes through traps (ovitraps, mosquiTRAPs, vacuums, baits, among other methods); entomological/larval surveys in reservoirs, tanks, vats, vases, tires; entomological survey in buildings by means of the Breteau index and the building infestation index-BII. The most frequent were the crosssectional epidemiological studies and also the ecological, descriptive, time-series studies, which used secondary data of the Sistema Nacional de Agravos de Notificação (SINAN - National Notifiable Diseases Database) and spatial analyses. Among the employed types of analyses, the highlights are correlations and geoprocessing techniques, especially through the Kernel method.

\section{Distribution of the studies}

Figures 2 and 3 show the number of publications according to areas of study by Federative Units, geographical regions and in conformity with the country's climate zones. Figure 2 shows that the largest 


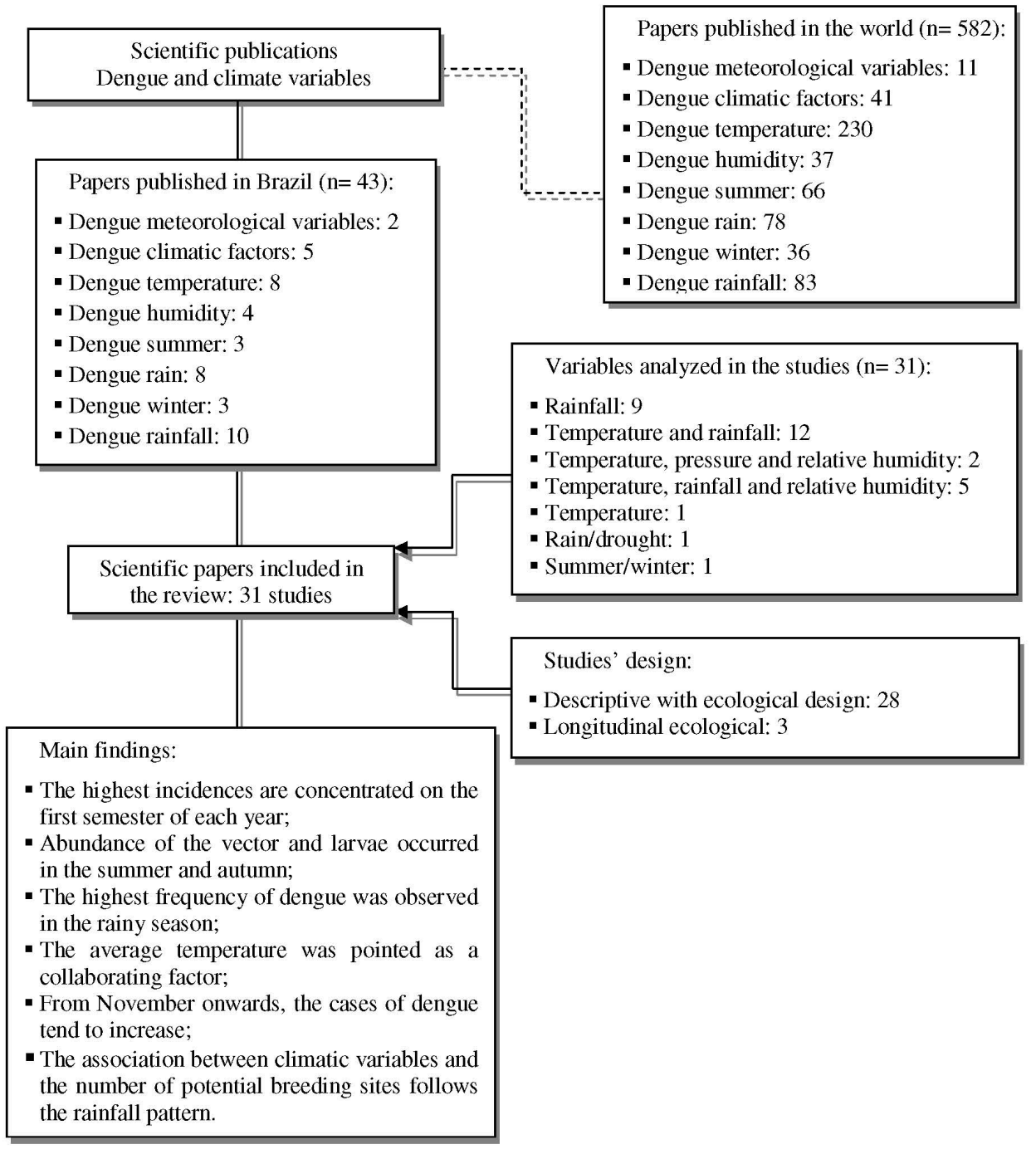

Figure 1 - Logical framework of the systematic review, the occurrence of dengue in Brazil and weather variations, publications from 1992 to 2010.

Figura 1 - Quadro lógico da revisão sistemática, a ocorrência da dengue e variações meteorológicas no Brasil, publicações de 1992 a 2010.

number of studies was conducted in the State of São Paulo, SP, followed by Rio de Janeiro, RJ. Studies were published about the entire Southeast region, except for the State of Espírito Santo. On the other hand, only one study was published about the South region, conducted in a city of the State of Paraná. Figure 3 shows the number of studies published by climate zones. It can be seen that studies were carried out in areas that are affected by the five Brazilian climates. Studies relating dengue to meteorological variables were more frequent in areas of the Central Brazil Tropical Climate.

Table 1 presents, in chronological order and by climate, the studies on the theme of dengue and meteorological variations in Brazil that were published between 1992 and 2010. In terms of temporal evolution, the highest number of publications occurred from the year 2000 onwards.

\section{Rainfall}

The abiotic factor rain ${ }^{22-29}$ was important for the production of larvae, pupae and 

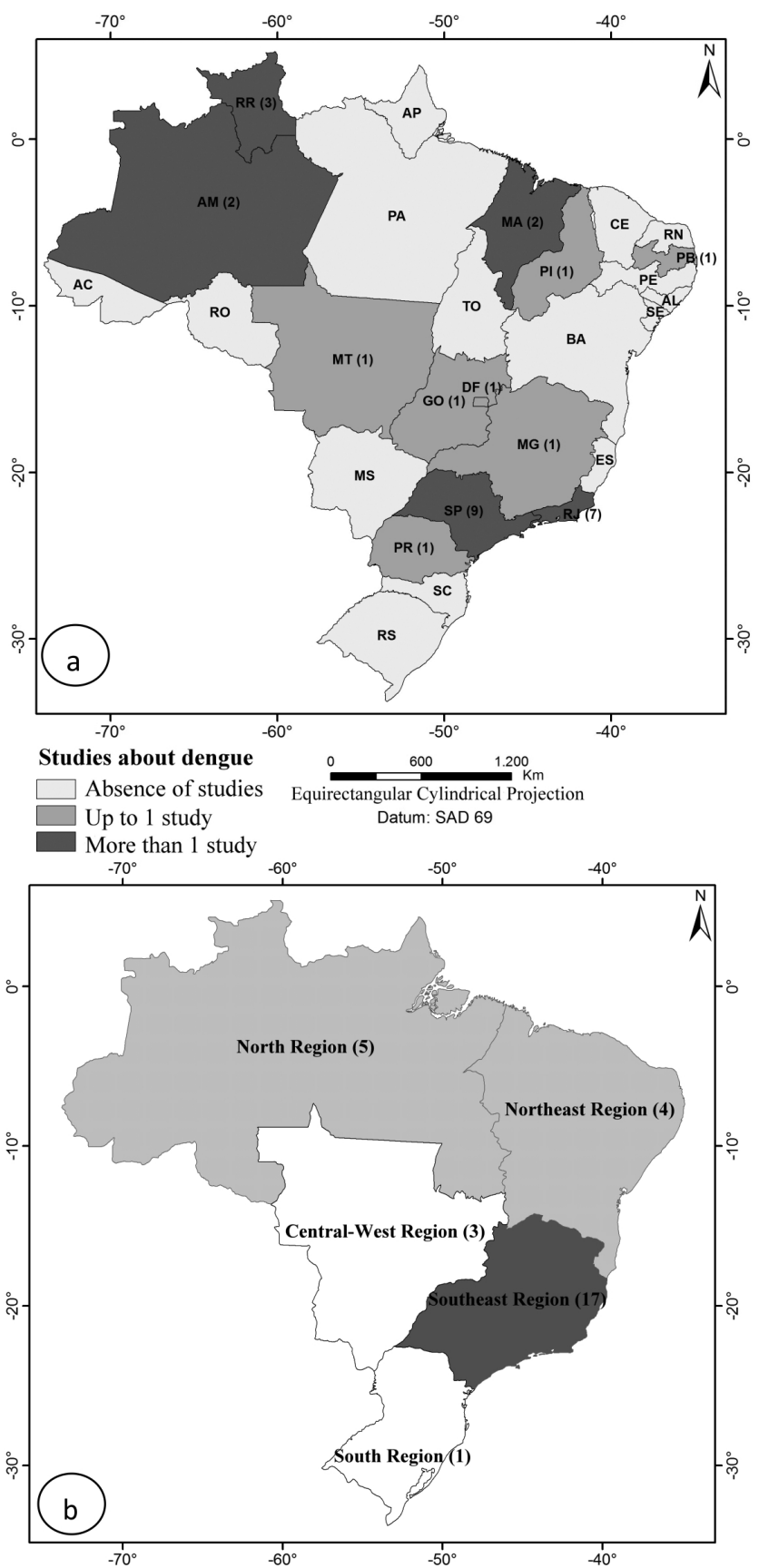

Studies about dengue $\quad$\begin{tabular}{lll}
0 & $500 \quad 1.000$ \\
\hline
\end{tabular}

Up to 3 studies Equirectangular Cylindrical Projection

Up to 5 studies

More than 5 studies

${ }^{*}$ A study conducted by Câmara et al. in 200730, not included in the map, analyzed simultaneously the 5 regions of Brazil.

* Publicação de Câmara et al. em 200730, não inclusa no mapa, analisou concomitantemente as 5 regiões do Brasil.

Figure 2 - Distribution of number of publications on dengue and climate variables in Brazil published between 1992 and 2010, according to the geographic area of study - (a) Unit of the Federation; (b) Geographic Region.

Figura 2 - Distribuição do número de publicações sobre dengue e variáveis meteorológicas no Brasil, publicadas entre 1992 e 2010, segundo área geográfica de estudo - (a) Unidade da Federação; (b) Região Geográfica. 


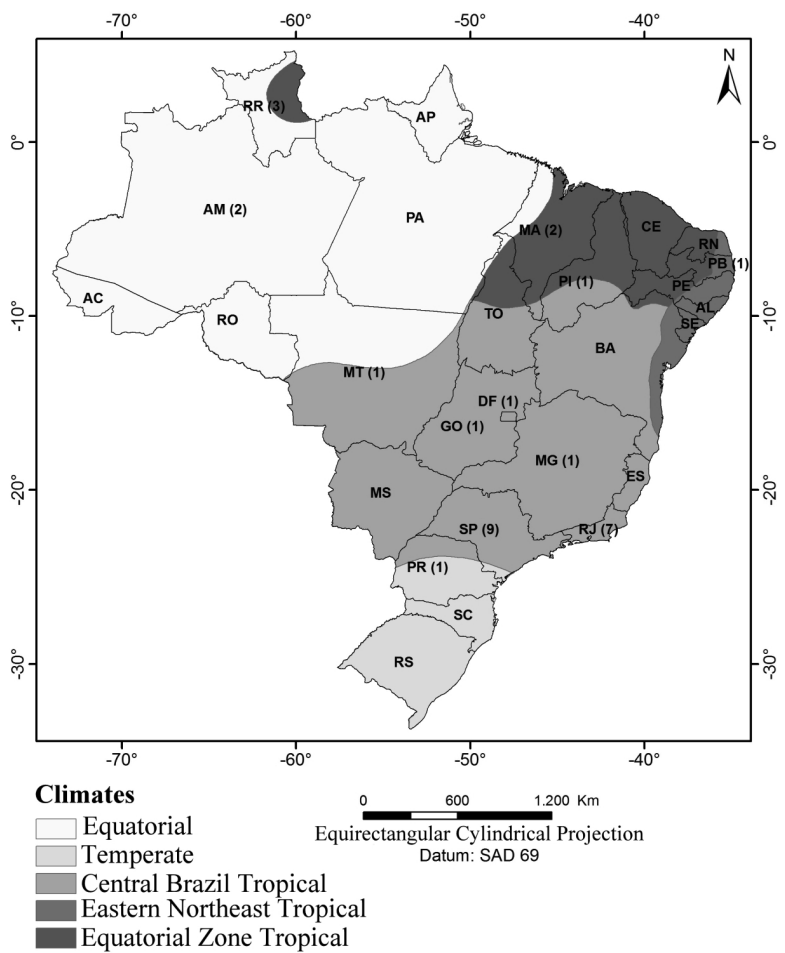

Figure 3 - Number of publications of dengue and climate variables in Brazil published between 1992 and 2010, according to climate category.

Figura 3 - Número de publicações sobre dengue e variáveis meteorológicas no Brasil publicadas entre 1992 e 2010, segundo o compartimento climático.

occurrence of dengue. The infestations occurred mainly in the months of highest rainfall levels at the different areas. Studies carried out in Vale do Paraíba (SP) 22 , São José do Rio Preto (SP) ${ }^{23}$, in the state of Maranhão $(\mathrm{MA})^{24}$, Vila das Pedrinhas (south coast of the state of São Paulo) ${ }^{25}$, Manaus (AM) ${ }^{26}$, Paraíba (PB) ${ }^{27}$, Uberlândia $(\mathrm{MG})^{28}$ and Boa Vista (RR) ${ }^{29}$ have shown that, even though there are differences in the rain dynamics in the several regions of Brazil, the highest incidence of the disease and the highest levels of vector infestations coincided with the rainy months, which were also the hottest months of the year in the country ${ }^{30}$.

A study conducted in all the 246 cities of the state of Goiás ${ }^{31}$ (Central-Western Brazil) from January 2001 to December 2005 showed that the building infestation index (BII) concerning Ae. Aegypti presented an important variability over the months, and also that there is a significant association between the peaks of the disease and periods of high BII and medium rainfall levels. Larval density and the number of dengue cases increased during the first four months of each year (period of high rainfall levels) and decreased between June and September (lower rainfall levels). These results were also found in studies conducted in São José do Rio Preto (SP) ${ }^{23}$, Maranhão (MA) ${ }^{24}$, Vila das Pedrinhas (SP) ${ }^{25}$ and Tupã (SP) ${ }^{32}$.

The climate of the state of Goiás is Central Brazil Tropical, with two well-defined seasons: extremely dry in the middle of the year and rainy in the summer, with a period of drought that lasts from 5 to 6 months (May to September) and a rainy season that lasts from October to April ${ }^{31}$. The climate of Goiás is similar to the climate of the other states located in the Central-West region and the cycles of rainfall seasonality are similar to those of the rest of Brazil, except for some regions of the Northeast, which have the Eastern Northeast Tropical climate, and of the Northern Amazon, which have 
Table 1 - Studies on dengue and climate variables in Brazil, published between 1992 to 2010.

Tabela 1 - Estudos sobre dengue e variáveis meteorológicas no Brasil, publicados entre 1992 a 2010.

References
Year of publication $\quad$ Area and period of the study $\quad$ Variable Main findings

\section{Central Brazil Tropical Climate}

Gomes et al. 1992 $22 \quad$ Vale do Paraíba, SP Temperature Rainfall was important for the production of larvae

Rev Saúde Públicac June 1989 to July $1990 \quad$ Rainfall and pupae, but the rain period does not coincide with maximum production. Abundance occurred in the summer-autumn seasons, and the highest peak was reached in March-April. Average temperature data suggested that the $17-23^{\circ} \mathrm{C}$ range is the most favorable to the vector's larval development.

\begin{tabular}{|c|c|c|c|}
\hline $\begin{array}{l}\text { Chiaravalloti Neto, } 1997^{23} \\
\text { Rev Soc Bras Med Trop }\end{array}$ & $\begin{array}{c}\text { São José do Rio Preto, SP } \\
\text { April to May } 1985\end{array}$ & Rainfall & $\begin{array}{l}\text { The major part of the household infestations by Ae- } \\
\text { des aegypti occurred between November and April, } \\
\text { the months of the highest incidence of rain in the } \\
\text { region, which shows an important association with } \\
\text { rainfall. }\end{array}$ \\
\hline
\end{tabular}

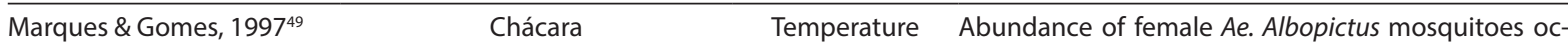

Rev Saúde Pública ${ }^{\mathrm{b}} \quad$ Tremembé, SP Rainfall

curred predominantly in the hottest and rainiest months (summer and beginning of autumn), mainly in January and February. Blood-feeding behavior predominated during the day, and it may occur during all year long.

\begin{tabular}{lc}
\hline Souza-Santos, $1999^{46}$ Rev & District of Galeão \\
Soc Bras Med Trop & Ilha do Governador, RJ \\
& June 1992 to July 1994
\end{tabular}

Temperature Representative values for temperature and relative Pressure air humidity were shown; it is believed that only the Relative humidity maximum temperatures exercise a strong influence on the larvae population. In the months when the highest indexes of relative air humidity occurred, the highest means of the numbers of positive breeding sites were observed.

\begin{tabular}{|c|c|}
\hline $\begin{array}{l}\text { Forattini et al. } 2000^{25} \text { Rev } \\
\text { Saúde Pública }{ }^{\mathrm{b}}\end{array}$ & $\begin{array}{c}\text { Vila de Pedrinhas, SP } \\
\text { October } 1996 \text { to January } 2000\end{array}$ \\
\hline
\end{tabular}

There was greater predominance of Ae. Scapularis compared to Ae. albopictus. In the rainy months, from January to May, Ae. Albopictus reached the most expressive values, while from July to October there was a higher productivity of adult Ae. Scapularis mosquitos.

\begin{tabular}{|c|c|c|}
\hline $\begin{array}{l}\text { Forattini et al. } 2001^{38} \text { Rev } \\
\text { Saúde Pública }\end{array}$ & $\begin{array}{l}\text { Vila de Pedrinhas, SP } \\
\text { November } 1996 \text { to March } 2000\end{array}$ & $\begin{array}{l}\text { Temperature } \\
\text { Rainfall }\end{array}$ \\
\hline
\end{tabular}

A total of 7,825 immatures was obtained, 2.397

(30.6\%) belonging to the species Aedes albopictus. There was no significant correlation with average temperature, rainfall and daily emergence of Aedes albopictus female adults; rather, there was the occurrence of higher values in the hottest and rainiest months (December-May).

Favier et al. $2006^{39}$ Trop Med Vila Planalto, DF Int Healthc
December 1997 to May 1999

\section{Temperature \\ Rainfall}

Relative humidity sites follows the rainfall pattern. The average number

The entomological indexes showed higher values in the rainy period; the number of potential breeding of pupae per positive reservoir is intimately associated with average temperature. Relative air humidity also influenced the number of positive reservoirs.

\begin{tabular}{lcc}
\hline $\begin{array}{l}\text { da Costa-Ribeiro et al. 2006 } \\
\text { Trop Med Int Health }\end{array}$ & $\begin{array}{c}\text { Rio de Janeiro, RJ } \\
\text { (14 cities) }\end{array}$ & Rainfall \\
& $\begin{array}{c}\text { December } 2002 \text { to December } \\
2003\end{array}$ & \\
& & \\
\hline $\begin{array}{l}\text { Ribeiro et al., } 2006^{9} \text { Rev } \\
\text { Saúde Pública }\end{array}$ & São Sebastião, SP & $\begin{array}{c}\text { Temperature } \\
\text { Rainfall }\end{array}$
\end{tabular}

The results of the collection of samples were higher in the rainy period compared to the dry period. High levels of genetic differentiation were detected, which tended to persist throughout the year; the differentiation of the genetic structure was greater in the rainy season.

An association was found between dengue incidence and abiotic factors (temperature and rainfall) from the second month onwards, up to the fourth month. Epidemic waves occurred from April to June. 
Table 1 - Studies on dengue and climate variables in Brazil, published between 1992 to 2010. (cont.)

Tabela 1 - Estudos sobre dengue e variáveis meteorológicas no Brasil, publicados entre 1992 a 2010. (cont.)

\begin{tabular}{|c|c|c|c|}
\hline $\begin{array}{l}\text { References } \\
\text { Year of publication }\end{array}$ & Area and period of the study & Variable & Main findings \\
\hline $\begin{array}{l}\text { Honório et al. } 2006^{37} \mathrm{Mem} \\
\text { Inst Oswaldo } \mathrm{Cruz}^{\mathrm{c}}\end{array}$ & $\begin{array}{c}\text { Ambaí, RJ } \\
\text { November } 1997 \text { to October } 1998\end{array}$ & $\begin{array}{c}\text { Temperature } \\
\text { Rainfall } \\
\text { Relative humidity }\end{array}$ & $\begin{array}{l}\text { Ae. albopictus was the dominant species in all the } \\
\text { tires. It was more abundant in the rainy season, and } \\
\text { pupae were found in the hotter months when the } \\
\text { volume of water was higher. Ae. Aegypti abundance } \\
\text { showed a less evident seasonal pattern. }\end{array}$ \\
\hline
\end{tabular}

Urbinatti et al. $2007^{52}$ Rev Saúde Pública

$\begin{array}{cc}\text { Parque Tietê, SP } & \text { Temperature } \\ \text { April } 2001 \text { to March } 2002 & \text { Rainfall }\end{array}$

Temperature
Rainfall

A positive correlation was found between: positivity $x$ rainfall $\left(r_{s}=0.69 ; p<0.001\right)$; positivity $x$ temperature $\left(r_{s}=0.35 ; p<0.001\right)$; number of individuals $x$ rainfall $\left(r_{s}=0.29 ; p<0.001\right)$ and number of individuals $x$ temperature $\left(r_{s}=0.13 ; p<0.05\right)$. The correlations suggest that rain was more influent than temperature, and the highest frequencies were observed in the hot and rainy period.

\begin{tabular}{lcc}
\hline $\begin{array}{l}\text { Maciel-de-Freitas et al. } \\
2008^{34} \text { Trop Med Int Health }{ }^{\mathrm{b}, \mathrm{c}}\end{array}$ & $\begin{array}{c}2 \text { districts of Rio de Janeiro, RJ } \\
\text { (Favela do Amorim and } \\
\text { Tubiacanga) } \\
2005\end{array}$ & $\begin{array}{c}\text { Rain } \\
\text { Drought }\end{array}$ \\
\hline $\begin{array}{l}\text { Costa et al. } 2008^{28} \text { Rev Soc } \\
\text { Bras Med Trop }{ }^{\mathrm{b}, \mathrm{c}}\end{array}$ & $\begin{array}{c}\text { Uberlândia, MG } \\
\text { March 2003 to February 2005 }\end{array}$ & $\begin{array}{c}\text { Temperature } \\
\text { Rainfall }\end{array}$
\end{tabular}

There was no significant statistical difference between the dry and rainy periods. The effect of seasonality was low or absent in the majority of the analyzed reservoirs.

Temperature and rainfall significantly influenced the increase in the number of breeding sites and the population dynamics of Ae. aegypti. It was found that $86.5 \%$ became positive in the rainy period, and only $13.5 \%$ in the dry period.

\begin{tabular}{lcc}
\hline Dibo et al. $2008^{43}$ Mem Inst & Mirassol, SP & Temperature \\
Oswaldo Cruz $^{c}$ & November 2004 to & Rainfall \\
& November 2005 &
\end{tabular}

Ae. aegypti proliferation, larvae and positivity for female eggs were more frequent in periods of higher temperatures and rainfall levels.

\begin{tabular}{lcc}
\hline Câmara et al. $2009^{36}$ Rev Soc & City of Rio de Janeiro, RJ & Temperature \\
Bras Med Tropa & 1986 to 2003 & Rainfall
\end{tabular}

Peaks of the epidemics were registered in the beginning of the summer of each year; a relationship was observed between the epidemic and temperature. Rainfall levels were not significant. The period of highest risk was considered: hot and dry summers, with minimum average temperature above $22^{\circ} \mathrm{C}$ and rain volume below $200 \mathrm{~mm} / \mathrm{month}$.

\begin{tabular}{|c|c|c|}
\hline $\begin{array}{l}\text { Honório et al. } 2009^{35} \\
\text { J Med Entomol }\end{array}$ & $\begin{array}{l}3 \text { districts of Rio de Janeiro, RJ } \\
\text { (Higienópolis, Tubiacanga and } \\
\text { Palmares) } \\
\text { September } 2006 \text { to March } 2008\end{array}$ & $\begin{array}{c}\text { Temperature } \\
\text { Rainfall }\end{array}$ \\
\hline
\end{tabular}

The entomological indexes showed an association between egg positivity and dengue incidence, mainly in the dry period (low rainfall levels). It is suggested that a monthly average temperature above $22-24^{\circ} \mathrm{C}$ is strongly associated with Ae. Aegypti abundance.

\begin{tabular}{ll}
\hline Miyazaki et al. $2009^{48}$ Rev & Campus of UFMT, Cuiabá, MT \\
Soc Bras Med Trop ${ }^{\mathrm{b}, \mathrm{c}}$ & August 2004 to August 2005
\end{tabular}

Temperature

Rainfall

Relatived (maximum, average and minimum) - signifiA significant association with temperature was re-
ported (maximum, average and minimum) - signifiRelative humidity cant values of Spearman's correlation only for maximum temperature. Rain was the factor that exercised an influence on the level of vector infestation. There was no significant association between number of eggs and relative air humidity.

\begin{tabular}{|c|c|c|c|}
\hline $\begin{array}{l}\text { Dos Reis et al. } 2010^{42} \text { Acta } \\
\text { Trop } \\
\text { b,c }\end{array}$ & $\begin{array}{c}3 \text { districts of Rio de Janeiro, RJ } \\
\text { (Higienópolis, Tubiacanga and } \\
\text { Palmares) } \\
2007\end{array}$ & $\begin{array}{l}\text { Summer } \\
\text { Winter }\end{array}$ & $\begin{array}{l}\text { Captures did not differ significantly across seasons, } \\
\text { but a higher number of eggs was obtained during } \\
\text { the summer. }\end{array}$ \\
\hline $\begin{array}{l}\text { Souza et al. } 2010^{31} \text { Rev Soc } \\
\text { Bras Med Trop }{ }^{\mathrm{a}, \mathrm{c}}\end{array}$ & $\begin{array}{c}\text { Goiás, GO } \\
\text { (All the } 246 \text { cities) } \\
\text { January } 2001 \text { to December } 2005\end{array}$ & Rainfall & $\begin{array}{l}\text { A strong association was found between peaks of } \\
\text { the disease and periods of higher Building Infesta- } \\
\text { tion Indexes - Bll of Ae. aegypti, rainfall and dengue } \\
\text { incidence. The number of cases of the disease was } \\
\text { higher during the first four months of each year (pe- } \\
\text { riod of high rainfall levels) and lower between June } \\
\text { and September (lower rainfall levels). }\end{array}$ \\
\hline
\end{tabular}


Table 1 - Studies on dengue and climate variables in Brazil, published between 1992 to 2010. (cont.)

Tabela 1 - Estudos sobre dengue e variáveis meteorológicas no Brasil, publicados entre 1992 a 2010. (cont.)

\begin{tabular}{|c|c|c|c|}
\hline $\begin{array}{l}\text { References } \\
\text { Year of publication }\end{array}$ & Area and period of the study & Variable & Main findings \\
\hline $\begin{array}{l}\text { Barbosa and Lourenço, } \\
2010^{32} \text { Rev Soc Bras Med } \\
\text { Trop }^{a, c}\end{array}$ & $\begin{array}{c}\text { Tupã, SP } \\
\text { January } 2004 \text { to December } 2007\end{array}$ & $\begin{array}{l}\text { Temperature } \\
\text { Rainfall }\end{array}$ & $\begin{array}{l}\text { A larger infestation occurred in the first quarter of } \\
\text { each year. There was an increasing incidence from } \\
\text { January to April, when it reaches its peak, followed } \\
\text { by a decrease, until the end of the epidemic in June. } \\
\text { Higher number of positive reservoirs in the hottest } \\
\text { and most humid months of the year. }\end{array}$ \\
\hline
\end{tabular}

\section{Eastern Northeast Tropical Climate}

Rebêlo et al. $1999^{24}$ Cad Maranhão, MA Rainfall The Building Infestation Indexes - Bll were higher

Saúde Pública ${ }^{a, b} \quad 87$ of the 136 cities from January to May (rainy period) and in Novem-

1995 to $1996 \quad$ ber (end of the dry period). The incidence of dengue followed a pattern that was similar to the rainfall regime. During the dry period there was a large decrease in the incidence of dengue.

\begin{tabular}{ll}
\hline Gonçalves Neto \& Rebêlo, & São Luiz, MA \\
$2004^{51}$ Cad Saúde Pública $^{a}$ & 1997 to 2002
\end{tabular}

Temperature

Rainfall

Relative humidity found over the years with rainfall $(r=0.84)$ and relative air humidity $(r=0.76)$, and a negative correlation with temperature $(r=-0.78)$.

\begin{tabular}{lcc}
\hline Monteiro et al. $2009^{40}$ & Teresina, PI & Temperature \\
Epidemiol. Serv. Saúde $^{\mathrm{a}}$ & 2002 to 2006 & Rainfall
\end{tabular}

A strong positive correlation was observed among dengue incidence, rainfall and temperature, particularly in the first semester of each year. The highest values of the Building Infestation Index - Bll coincided with the highest rainfall indexes.

\begin{tabular}{|c|c|c|c|}
\hline $\begin{array}{l}\text { Souza et al. } 2007^{27} \text { Cad } \\
\text { Saúde Pública }\end{array}$ & $\begin{array}{c}\text { Paraíba, PB } \\
\text { January } 1998 \text { to June } 2005\end{array}$ & Rainfall & $\begin{array}{l}\text { A different incidence curve of dengue was observed } \\
\text { in each year. The peaks oscillate from March to May } \\
\text { (summer/autumn), similarly to rainfall. }\end{array}$ \\
\hline
\end{tabular}

\section{Equatorial Climate}

Pinheiro \& Tadei, $2002^{26}$ Rev Inst Med Trop São Paulo ${ }^{c}$
Manaus, AM

January to November 1999

Rainfall

The highest mean of Aedes aegypti positivity occurred in the period of high rainfall levels, mainly in the month of April. In the dry period, there was a decrease in the average productivity and positivity of the larvae.

\begin{tabular}{|c|c|c|c|}
\hline $\begin{array}{l}\text { Ríos-Velásquez et al. } 2007^{33} \\
\text { Mem Inst Oswaldo Cruz }\end{array}$ & $\begin{array}{c}4 \text { districts of Manaus, AM } \\
\text { (Chapada, Coroado, Flores and } \\
\text { Tancredo Neves) } \\
2004\end{array}$ & Rainfall & $\begin{array}{l}\text { The lowest prevalence values were observed in the } \\
\text { dry season (August), when Ae. Aegypti was found in } \\
84-90 \% \text { of the households. The highest values were } \\
\text { found in November (transition period), with } 94-98 \% \\
\text { of positive households. }\end{array}$ \\
\hline
\end{tabular}

\section{Equatorial Zone Tropical Climate}

Rosa-Freitas et al. $2006^{53}$

Rev Panam Salud Publica ${ }^{a} \quad$ September 1998 to December 2001

Zeidler et al. $2008^{29}$ Rev Saúde Pública ${ }^{\mathrm{a}, \mathrm{c}}$

Boa Vista, RR

November 2006 to May 2007
Temperature

Pressure

Relative humidity

Wind direction
The correlations ranged from strong to moderate, with significant statistical differences. Seasonal relay tion was larger than daily correlations.
Rainfall

A positive correlation was verified between number of eggs and rainfall index, which suggests that the rain contributed to increase the number of breeding sites, but it did not correlate with the incidence of dengue. Peaks of dengue incidence occur both in the rainy and in the dry periods.

The vector presented the highest infestation rates during the rainy season (May-August), and high indexes also during the beginning of the dry season (November), showing a great variability over the years. 
Table 1 - Studies on dengue and climate variables in Brazil, published between 1992 to 2010. (cont.)

Tabela 1 - Estudos sobre dengue e variáveis meteorológicas no Brasil, publicados entre 1992 a 2010. (cont.)

\begin{tabular}{|c|c|c|c|}
\hline $\begin{array}{l}\text { References } \\
\text { Year of publication }\end{array}$ & Area and period of the study & Variable & Main findings \\
\hline \multicolumn{4}{|l|}{ Temperate Climate } \\
\hline $\begin{array}{l}\text { Oliveira et al. } 2007^{50} \text { Arq. } \\
\text { Ciênc. Saúde Unipar }\end{array}$ & $\begin{array}{c}\text { Toledo, PR } \\
\text { January } 2001 \text { to December } 2005\end{array}$ & $\begin{array}{c}\text { Temperature } \\
\text { Rainfall } \\
\text { Relative humidity }\end{array}$ & $\begin{array}{l}\text { The rainfall data referring to the months of highest } \\
\text { number of notification of cases showed a slight rela- } \\
\text { tionship among one another. The statistical analysis } \\
\text { by the Chi-Square method did not show a correlation } \\
\text { between Ae. Aegypti infestation and relative air hu- } \\
\text { midity. Temperature variation contributed in a more } \\
\text { significant way, with a mean correlation of } 40 \% \text {. }\end{array}$ \\
\hline
\end{tabular}

All climates simultaneously

Câmara et al. $2007^{30}$ Rev Soc (North, Northeast, Center-West, Temperature Bras Med Trop ${ }^{\mathrm{a}}$
Southeast and South)

1986 to 2003
The major part of the disease notifications occurred in the hottest months, corresponding to the first semester of the year. Values are associated with high demographic indexes, and there are significant differences among regions. the Equatorial Zone Tropical Climate 20,21 .

There are studies that show the incidence rate of the disease by seasons. In Manaus, a lower incidence of dengue was verified in the dry season, when the $A e$. Aegypti mosquito was found in $84-90 \%$ of the houses, while the highest values were verified in November (transition/rainy period), with $94-98 \%$ of positive households $^{33}$. It is known that, in Manaus, the predominant climate is the Equatorial one ${ }^{20}$, with the rainy season lasting from January to May and the dry season, from July to September ${ }^{33}$.

A study carried out in $2005^{34}$ in the city of Rio de Janeiro showed that there was no statistically significant difference in infestation between the two periods, and the seasonality effect was described as being low or absent in the majority of the reservoirs analyzed in that city. Honório et al. ${ }^{35}$, in a study that was also conducted in Rio de Janeiro about the temporal distribution of $A e$. Aegypti between September 2006 and March 2008, found an important association with positive ovitraps. In the summer, the average indexes were of $70-80 \%$, reaching expressive peaks of $90-100 \%$, while in the winter, the infestation suffered a reduction, but it rarely remained below $60 \%$, which shows that the mosquito is prevalent all year long. The largest abundance was found in the hottest and most humid period of the year, indicating seasonality ${ }^{35}$. Rio de Janeiro has the Central Brazil Tropical climate ${ }^{20}$ and its temperature varies between $20^{\circ} \mathrm{C}$ and $27^{\circ} \mathrm{C}$. The hottest months occur between November and April, and the coldest, between May and October. Rain is most frequent between December and March (January is the rainiest month), and the driest period occurs from June to September ${ }^{36}$, similarly to the majority of the Brazilian states.

Many studies that employed ento-

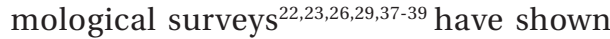
higher values of infestation of eggs, larvae and vectors in the rainy period; however, the positive breeding sites persist in the drought period, a fact that is favored by the mosquito's facility to adapt to the human environment, through natural and/or artificial reservoirs ${ }^{31,34,40,41}$.

\section{Rainfall and temperature}

A study carried out between March 2003 and February 2005 in three districts of high incidence of dengue in the city 
of Uberlândia, State of Minas Gerais, Southeastern Brazil, showed that temperature and rainfall influenced significantly the increase in the number of breeding sites and the Ae. Aegypti population dynamics. In the rainy period, $86.5 \%$ of the exposed traps became positive and only $13.5 \%$ in the dry period. When Costa et al. ${ }^{28}$ analyzed colder and drier periods of the year (less favorable conditions to the development of the mosquito), they observed a sharp reduction in the adult population of the vector but, although in a lower proportion, the mosquito was also present in the colder and drier months of the year. This fact has also been described by Dos Reis et al. ${ }^{42}$, who used oviposition traps in 3 districts of the city of Rio de Janeiro, in the summer (January to March) and in the winter (June to September) of 2007; although the captures did not differ, a higher number of eggs and female adults was verified during the summer.

Dibo et al. ${ }^{43}$, by means of weekly collections of eggs and larvae in the city of Mirassol, state of São Paulo, Southeastern region of Brazil, from November 2004 to November 2005, confirmed the results that have already been described here about $A e$. aegypti proliferation, which shows that the number of eggs, larvae and mosquitoes is larger in periods of higher temperatures and rainfall indexes ${ }^{25,26,37,44}$.

Monteiro el al. ${ }^{40}$ analyzed the epidemiological indicators of dengue in the city of Teresina, state of Piauí, from 2002 to 2006. The authors found a positive correlation between the incidence of dengue, rainfall and temperature, particularly in the first semester of each year, the period with the highest rainfall index and building infestation, mainly in the months of March to May 2002-2003. Such findings corroborate the study conducted by Barbosa and Lourenço ${ }^{32}$ in the interior of the State of São Paulo, in the city ofTupã, from January 2004 to December 2007. Larger infestations were noticed in the first quarter of each year, as well as a decrease in the epidemic in June, and an increase in the number of positive reservoirs in the hottest and most humid months of the year (January to April).

In the city of Rio de Janeiro, between 1986 and 2003, it was observed that the largest risk factors for dengue epidemics were: minimum average temperature above $22^{\circ} \mathrm{C}$, and hotter and drier summers. The most relevant temperature was that of the first quarter of the analyzed period. It was found that, in the years in which the epidemics occurred, the temperatures were significantly higher when compared to those of the other years. There was no important association between the incidence of the disease and rainfall. The epidemics were more frequent in the years in which the rainfall volume was below $200 \mathrm{~mm} / \mathrm{month}^{36}$.

Câmara et al. ${ }^{30}$ conducted a time-series study of dengue between 1986 and 2003 in the five regions of Brazil. This study showed that the Northeast and Southeast regions corresponded to approximately $86 \%$ of the disease notifications, while the Central-West (7.6\%), North (5.7\%) and South (1.2\%) regions presented a lower number of registers. In 2003, the Northeast and Southeast regions had $70.5 \%$ of the Brazilian population, that is, even taking each region's population into account, the disease was more incident in those two regions. In the Southeast, Central-West and South regions, more than half of the cases occurred in the first quarter, while in the Northeast region, it occurred in the second quarter of the year.

However, the epidemiological data of 2008 and 2010 show a change in the distribution pattern of dengue in the country. In 2010 , more than one million probable cases of the disease were registered due to the re-circulation of DENV-1, and $63 \%$ of the cases occurred in the Central-West and Southeast regions, mainly in cities of the States of Rio de Janeiro, Mato Grosso and Mato Grosso do Sul ${ }^{45}$.

The notifications peaks analyzed by the authors ${ }^{30}$ are in agreement with the studies analyzed here. In short, they are concentrated particularly on the first half of each year, a period that is considered the hottest and most humid of the year. In the months 
in which the temperature decreases, in the second half of the year, it was found that the incidence declined, which shows that the dynamics of the vector and of the disease depends on seasonal variation.

\section{Temperature and relative air humidity}

The analysis of an entomological survey that was carried out during 82 weeks, from September 2006 to March 2008, and used ovitrap and mosquiTRAP, showed an important association between the number of positive eggs and incidence of dengue, mainly in the dry period (low rainfall level). The authors ${ }^{35}$ suggest that the monthly average temperature above $22-24^{\circ} \mathrm{C}$ is strongly associated with Ae. Aegypti abundance and, consequently, with a higher risk of dengue transmission.

Favier et al. ${ }^{39}$ argued that the number of potential breeding sites follows the rain pattern, but the values are not annulled in the drought period. The mean number of pupae per positive reservoir is intimately associated with the average temperature. It was considered that the variable relative air humidity also favored the number of positive reservoirs in Vila Planalto, Brasília. Similar results in relation to the city of São Sebastião, state of São Paulo ${ }^{9}$, indicated that the highest values of temperature and relative air humidity were registered from November to April, and it was during these months that the highest indexes of $\mathrm{Ae}$. Aegypti larval density were observed.

A study conducted in the District of Galeão, Ilha do Governador, RJ, between June 1992 and July 1994, revealed that probably only the temperature extremes exercised a differentiated effect on the larvae population. In the following months, or right after the observation of higher registers of relative air humidity, the highest means of the number of positive breeding sites were noted, as well as negative correlations concerning the mean atmospheric pressure ${ }^{46}$. Average temperatures between 17 and $23^{\circ}$ C were reported as the most favorable for larval development ${ }^{22}$.
The data described above are corroborated by entomological laboratory studies. The embryonic development of the Ae. Aegypti mosquito was analyzed under the influence of temperature variation and it was observed that the viability of eggs between $16-31^{\circ} \mathrm{C}$ was higher than $80 \%$; between $22-28^{\circ} \mathrm{C}$, it was higher than $90 \%$. Farnesi et al. ${ }^{47}$ highlight that these temperature ranges favor the Ae. Aegypti presence in the tropical and subtropical regions of the world.

Miyazaki et al ${ }^{48}$ carried out a monitoring study that employed ovitraps in the city of Cuiabá, state of Mato Grosso, between August 2004 and August 2005. Cuiabá is one of the hottest capital cities of Brazil, with maximum averages around $31^{\circ} \mathrm{C}$. This study showed a significant correlation with maximum, average and minimum temperature. However, the authors ${ }^{48}$ considered that rainfall was the only determinant factor for infestation level. The frequency of egg collection showed an increase in the months of October and December, totaling $49 \%$ and $36.8 \%$, respectively. A larger presence of females was observed in the months of July and August and there was no association between number of eggs and relative air humidity. The number of collections did not follow one single distribution pattern over the period. It could occur during the whole year, as it has been shown in other studies ${ }^{28,43,49}$.

\section{Lag}

In spite of the fact that meteorological variations are an important predictor, it is known that in the majority of the situations there is a time lag, that is, a lag in the association between meteorological variables and the occurrence of dengue or the emergence of new larvae/mosquitoes in the same month.

Ribeiro et al. ${ }^{9}$ analyzed the time lag of the association between the number of cases of dengue and abiotic factors (rain and temperature) in the city of São Sebastião, state of São Paulo, from 2001 to 2002. The authors identified that the lag revealed a significant 
association in the second, third and fourth months of observation, that is, the rain and temperature of a given month contributed to explain the number of cases of dengue two to four months later.

The analysis of the incidence of dengue in the state of Paraíba through distributed lag models found that the coefficients decrease up to the fourth month and increase again in the fifth month. The beginning of the annual growth curves occurs five months in advance, which corresponds to a five-month lag. Therefore, a different curve of dengue incidence occurred in each year, and the peaks oscillate between the months of March and May. For this reason, Souza et al. ${ }^{27}$ stated that the five-month lag corresponds to the duration of the period that is necessary for a change to occur in the trend of the annual curve of dengue incidence, from the beginning of the summer onwards.

Oliveira et al..$^{50}$, in a study carried out in the city of Toledo, state of Paraná, from November 2001 to July 2002, observed a $20.5 \%$ correlation regarding the influence of rainfall on the number of confirmed cases in the following month. This correlation practically does not exist concerning two or three months after the rain period.

\section{Final remarks}

The research showed that meteorological factors such as temperature, relative air humidity and rainfall, mentioned in the studies analyzed here, influenced the vector dynamics, as well as the peaks of the dengue epidemics in Brazil, independently of the climate zone. The occurrence of the disease is associated with increased rainfall indexes and with temperature variations, mainly in the first semester of each year. This is the period of highest temperature and rainfall levels in the largest part of Brazil, which contributes to increase the number of breeding sites and, consequently, the number of cases of dengue.

Even though this disease is typically seasonal, cases of dengue are registered both in the rainy and dry periods, as the reduction in the vector density of adults in the cold and dry months is not enough to cease the disease transmission. There are, however, countless difficulties in establishing a "key" seasonal pattern of the incidence of the disease and of the meteorological variables, due to the fact that the vector's blood-feeding pattern occurs predominantly during the whole year, with different intensities.

Brazil's large territorial dimension must be taken into account, as well as its border with neighboring countries, the diversity of biomes, lack of urban infrastructure, and favorable meteorological and environmental characteristics during almost the whole year, which facilitate the maintenance of the disease. In the majority of the studies analyzed here, the highest vector density coincides with the rainy period, suggesting that rainfall is the most important abiotic factor for the increase in the vector population. In this sense, it should be highlighted that the rain cycle in Brazil has peculiar characteristics, according to the different climate zones in the distinct geographical regions. There is no homogeneous distribution of rainfall levels in the national territory.

Other relevant aspects are the genetic complexity of the vector and the circulation of different serotypes, which are likely to influence the dengue distribution, both in the dry and rainy periods, and the vector's capacity to adapt to the human environment through breeding sites. Therefore, the vector does not depend exclusively on abiotic factors. It survives in low density during the months that are less favorable in climatic terms, which shows the relevance of maintaining the actions of vector surveillance and control during the entire year.

As this is a scientific literature review, the study is potentially conditioned to the biases of the reviewed studies, that is, it depends on the findings contained in the publications. Another bias concerns the distribution of the studies, which was concentrated particularly on some States. Based on this systematic review, it was found that all the Brazilian climates were represented if the areas of study are considered. However, 
the best represented climate was the Central

Brazil Tropical Climate, which coincides with the most populated area, and also with the most endemic area of the country.

It is concluded that dengue is strongly related to meteorological variables. The seasonal variation of temperature and rainfall influenced the vector dynamics and the incidence of the disease in the entire country, independently of the climate zone.

\section{References}

1. da Silva-Voorham JM, Tami A, Juliana AE, RodenhuisZybert IA, Wilschut JC, Smit JM. Dengue: a growing risk to travellers to tropical and sub-tropical regions. Ned Tijdschr Geneeskd 2009; 153: A778.

2. Pinheiro FP, Corber SJ. Global situation of dengue and dengue haemorrhagic fever, and its emergence in the Americas. World Health Stat Q 1997; 50(3-4): 161-9.

3. Wilder-Smith A, Chen LH, Massad E, Wilson ME. Threat of dengue to blood safety in dengue-endemic countries. Emerg Infect Dis 2009; 15(1): 8-11.

4. World Health Organization. Report of the Scientific Working Group meeting on Dengue. Geneva; 2006.

5. World Health Organization. WHO report on global surveillance of epidemic-prone infectious diseases. Geneva; 2000.

6. Sutherst RW. Global change and human vulnerability to vector-borne diseases. Clin Microbiol Rev 2004; 17(1): 136-73.

7. Brasil. Ministério da Saúde. Mudanças climáticas e ambientais e seus efeitos na saúde: cenários e incertezas para o Brasil. Organização Pan-Americana da Saúde. Brasília; 2008.

8. Dhiman RC, Pahwa S, Dhillon GP, Dash AP. Climate change and threat of vector-borne diseases in India: are we prepared? Parasitol Res 2010; 106(4): 763-73.

9. Ribeiro AF, Marques GR, Voltolini JC, Condino ML. Associação entre incidência de dengue e variáveis climáticas. Rev Saúde Pública 2006; 40(4): 671-6.

10. Hales S, de Wet N, Maindonald J, Woodward A. Potential effect of population and climate changes on global distribution of dengue fever: an empirical model. Lancet 2002; 36(9336): 830-4.

11. Hemmer CJ, Frimmel S, Kinzelbach R, Gürtler L, Reisinger EC. Global warming: trailblazer for tropical infections in Germany? Dtsch Med Wochenschr 2007; 132(48): 2583-9.

12. Campbell-Lendrum D, Corvalán C. Climate Change and Developing-Country Cities: Implications For Environmental Health and Equity. J Urban Health 2007; 84(S1): 109-17.
13. Tabachnick WJ. Challenges in predicting climate and environmental effects on vector-borne disease episystems in a changing world. J Exp Biol 2010; 213(6): 946-54.

14. Osanai $\mathrm{CH}$, Travassos da Rosa AP, Tang AT, do Amaral RS, Passos AD, Tauil PL. Surto de dengue em Boa Vista, Roraima Nota previa. Rev Inst Med Trop Sâo Paulo 1983; 25(1): 53-4.

15. Schatzmayr HG. Dengue situation in Brazil by year 2000 Mem Inst Oswaldo Cruz 2000; 95 (S1): 179-81.

16. Schatzmayr HG, Nogueira RMR, Travassos da Rosa AP. An outbreak of dengue virus at Rio de Janeiro - 1986. Mem Inst Oswaldo Cruz 1986; 81(2): 245-6.

17. Brasil. Fundação Nacional de Saúde. Centro Nacional de Epidemiologia. Boletim eletrônico epidemiológico. Brasília; 2001.

18. Brasil. Ministério da Saúde. Informe Epidemiológico da Dengue/Análise de situação e tendências. Brasília; 2010.

19. Organização Pan-Americana da Saúde. Mudança Climática e Saúde: um perfil do Brasil. Brasíli; 2009.

20. Instituto Brasileiro de Geografia e Estatística [homepage na internet]. Brasília: Ministério do Planejamento, Orçamento e Gestão; 2005. Disponível em: http:// mapas.ibge.gov.br/clima/ viewer.htm (Acessado em 28 de fevereiro de 2012).

21. Mendonça FA, Danni-Oliveira IM. Climatologia - Noções básicas e climas do Brasil. São Paulo: Oficina de textos; 2007.

22. Gomes Ade C, Forattini OP, Kakitani I, Marques GR, Marques CC, Marucci D et al. Microhabitats de Aedes albopictus (Skuse) na região do Vale do Paraíba, Estado de São Paulo, Brasil. Rev Saude Publica 1992; 26(2): 10818.

23. Chiaravalloti Neto F. Descrição da colonização de Aedes aegypti na região de São José do Rio Preto, São Paulo. Rev Soc Bras Med Trop 1997; 30(4): 279-85.

24. Rebêlo JM, Costa JM, Silva FS, Pereira YN, da Silva JM. Distribuição de Aedes aegypti e do dengue no Estado do Maranhão, Brasil. Cad Saúde Pública 1999; 15(3): 477-86. 
25. Forattini OP, Kakitani I, dos Santos RLC, Kobayashi KM, Ueno HM, Fernandez Z. Comportamento de Aedes albopictus e Ae. scapularis adultos (Diptera: Culicidae) no sudeste do Brasil. Rev Saúde Pública 2000; 34(5): 4617.

26. Pinheiro VC, Tadei WP. Frequency, diversity, and productivity study on the Aedes aegypti most preferred containers in the city of Manaus, Amazonas, Brazil. Rev Inst Med Trop Sao Paulo 2002; 44(5): 245-50.

27. Souza IC, Vianna RP, Moraes RM. Modelagem da incidência do dengue na Paraíba, Brasil, por modelos de defasagem distribuída. Cad Saúde Pública 2007; 23(11): 2623-30.

28. Costa FS, Silva JJ, Souza CM, Mendes J. Dinâmica populacional de Aedes aegypti (L) em área urbana de alta incidência de dengue. Rev Soc Bras Med Trop 2008; 41(3): 309-12.

29. Zeidler JD, Acosta PO, Barrêto PP, Cordeiro Jda D. Dengue virus in Aedes aegypti larvae and infestation dynamics in Roraima, Brazil. Rev Saude Publica 2008; 42(6): 986-91.

30. Câmara FP, Theophilo RL, dos Santos GT, Pereira SR, Câmara DC, de Matos RR. Estudo retrospectivo (histórico) da dengue no Brasil: características regionais e dinâmicas. Rev Soc Bras Med Trop 2007; 40(2): 192-6.

31. Souza SS, Silva IG, Silva HHG. Associação entre incidência de dengue, pluviosidade e densidade larvária de Aedes aegypti, no Estado de Goiás. Rev Soc Bras Med Trop 2010; 43(2): 152-5.

32. Barbosa GL, Lourenço RW. Análise da distribuição espaço-temporal de dengue e da infestação larvária no município de Tupã, Estado de São Paulo. Rev Soc Bras Med Trop 2010; 43(2): 145-51.

33. Ríos-Velásquez CM, Codeço CT, Honório NA, Sabroza PS, Moresco M, Cunha IC et al. Distribution of dengue vectors in neighborhoods with different urbanization types of Manaus, state of Amazonas, Brazil. Mem Inst Oswaldo Cruz 2007; 102(5): 617-23.

34. Maciel-de-Freitas R, Peres RC, Souza-Santos R, Lourenço-de-Oliveira R. Occurrence, productivity and spatial distribution of key-premises in two dengueendemic areas of Rio de Janeiro and their role in adult Aedes aegypti spatial infestation pattern. Trop Med Int Health 2008; 13(12): 1488-94.

35. Honório NA, Codeço CT, Alves FC, Magalhães MA, Lourenço-De-Oliveira R. Temporal distribution of Aedes aegypti in different districts of Rio de Janeiro, Brazil, measured by two types of traps. J Med Entomol 2009; 46(5): 1001-14.

36. Câmara FP, Gomes AF, Santos GT, Câmara DC. Clima e epidemias de dengue no Estado do Rio de Janeiro. Rev Soc Bras Med Trop 2009; 42(2): 137-40.
37. Honório NA, Cabello PH, Codeço CT, Lourenço-deOliveira R. Preliminary data on the performance of Aedes aegypti and Aedes albopictus immatures developing in water-filled tires in Rio de Janeiro. Mem Inst Oswaldo Cruz 2006; 101(2): 225-8.

38. Forattini OP, Kakitani I, Ueno HM. Emergência de Aedes albopictus em recipientes artificiais. Rev Saude Publica 2001; 35(5): 456-60.

39. Favier C, Degallier N, Vilarinhos PT, de Carvalho MS, Yoshizawa MA, Knox MB. Effects of climate and different management strategies on Aedes aegypti breeding sites: a longitudinal survey in Brasília (DF, Brazil). Trop Med Int Health 2006; 11(7): 1104-18.

40. Monteiro ESC, Coelho ME, da Cunha IS, Cavalcante MAS, Carvalho FAA. Aspectos epidemiológicos e vetoriais da dengue na cidade de Teresina, Piauí - Brasil, 2002 a 2006. Epidemiol Serv Saúde 2009; 18(4): 365-74.

41. Codeço CT, Honório NA, Ríos-Velásquez CM, Santos Mda C, Mattos IV, Luz SB, et al. Seasonal dynamics of Aedes aegypti (Diptera: Culicidae) in the northernmost state of Brazil: a likely port-of-entry for dengue virus 4 . Mem Inst Oswaldo Cruz 2009 Jul; 104(4): 614-20.

42. Dos Reis IC, Honório NA, Codeço CT, Magalhães Mde A, Lourenço-de-Oliveira R, Barcellos C. Relevance of differentiating between residential and non-residential premises for surveillance and control of Aedes aegypti in Rio de Janeiro, Brazil. Acta Trop 2010; 114(1): 37-43.

43. Dibo MR, Chierotti AP, Ferrari MS, Mendonça AL, Chiaravalloti Neto F. Study of the relationship between Aedes (Stegomyia) aegypti egg and adult densities, dengue fever and climate in Mirassol, state of São Paulo, Brazil. Mem Inst Oswaldo Cruz 2008; 103(6): 554-60.

44. da Costa-Ribeiro MC, Lourenço-de-Oliveira R, Failloux AB. Geographic and temporal genetic patterns of Aedes aegypti populations in Rio de Janeiro, Brazil. Trop Med Int Health 2006; 11(8): 1276-85.

45. Siqueira JrJB, Vinhal LC, Said RFC, Hoffmann JL, Martins J, Barbiratto SB et al. Dengue no Brasil: tendências e mudanças na epidemiologia, com ênfase nas epidemias de 2008 e 2010. In: Saúde Brasil 2010: uma análise da situação de saúde e de evidências selecionadas de impacto de ações de vigilância em saúde. Brasília: Ministério da Saúde; 2011. pp. 159-171.

46. Souza-Santos R. Fatores associados à ocorrência de formas imaturas de Aedes aegypti na Ilha do Governador, Rio de Janeiro, Brasil. Rev Soc Bras Med Trop 1999; 32(4): 373-82.

47. Farnesi LC, Martins AJ, Valle D, Rezende GL. Embryonic development of Aedes aegypti (Diptera: Culicidae): influence of different constant temperatures. Mem Inst Oswaldo Cruz 2009; 104(1): 124-6. 
48. Miyazaki RD, Ribeiro AL, Pignatti MG, Campelo JHJr, Pignati M. Monitoring of Aedes aegypti mosquitoes (Linnaeus, 1762) (Diptera: Culicidae) by means of ovitraps at the Universidade Federal de Mato Grosso Campus, Cuiabá, State of Mato Grosso. Rev Soc Bras Med Trop 2009; 42(4): 392-97.

49. Marques GR, Gomes Ade C. Comportamento antropofílico de Aedes albopictus (Skuse) (Diptera: Culicidae) na região do Vale do Paraíba, Sudeste do Brasil. Rev Saúde Pública 1997; 31(2): 125-30.

50. Oliveira CL, Bier VA, Maier CR, Rorato GM, Frost KF; Barbosa MA et al. Incidência da dengue relacionada às condições climáticas no município de Toledo - PR. Arq Ciências Saúde UNIPAR 2007; 11(3): 211-6.
51. Gonçalves Neto, VS, Rebêlo, JMM. Epidemiological characteristics of dengue in the Municipality of São Luís, Maranhão, Brazil, 1997-2002. Cad Saúde Pública 2004; 20(5): 1424-31.

52. Urbinatti PR, Menezes RM, Natal D. Sazonalidade de Aedes albopictus em área protegida na cidade de São Paulo, Brasil. Rev Saúde Pública 2007; 41(3): 478-81.

53. Rosa-Freitas MG, Schreiber KV, Tsouris P, Weimann ET, Luitgards-Moura JF. Associations between dengue and combinations of weather factors in a city in the Brazilian Amazon. Rev Panam Salud Publica 2006; 20(4): 256-267.

Received: $12 / 03 / 12$

Approved: 10/07/12 